Original Research

\title{
Perancangan Human Resource Scorecard untuk Mengevaluasi Kinerja Divisi Rekrutmen XYZ Group
}

\author{
Marten Erwin ${ }^{1}{ }^{*}$, Eric Wibisono ${ }^{1}$, Mochammad Arbi Hadiyat ${ }^{1}$ \\ ${ }^{1}$ Teknik Industri, Fakultas Teknik Universitas Surabaya, Raya Kalirungkut Surabaya-Indonesia 60293 \\ * corresponding author: erwinmarten4@gmail.com
}

\begin{abstract}
XYZ Group has been expanding their bussiness in various sector i.e., retail, IT consultants, food \& beverages, shopping plazas, Japanese restaurants, e-wallets, e-commerce, and expeditions. XYZ Group continues to expand as an action to survive and win the competition. Therefore, XYZ Group's Recruitment Division plays an important role in business activities. The Human Resource Scorecard is an appropriate method for measuring performance in XYZ Group's recruitment division. The result of Human Resource Scorecard in the XYZ Group Recruitment Division are acquiring 17 Key Performance Indicators (KPI) consisting of financial perspective two KPIs, three customer perspective KPIs, eight operational perspective KPIs, and four strategic perspective KPIs. Performance measurement is carried out by weighting process, followed by performance measurement based on the required data. The measurement results show an overall performance of XYZ's Recruitment Division is 3,534, which means the performance of the XYZ Group's Recruitment Division is good. Financial perspective performance gets a value of 2.5 (good enough), customer perspective performance gets a value of 3,831 (good), operational perspective performance gets a value of 3,423 (good), and strategic perspective performance gets a value of 4 (good). Based on the KPI that didn't reach the target, an action plan was made. In addition to the action plan, performance dashboard and analysis of cause and effect relationships after measurement have been made.
\end{abstract}

Keywords: human resource scorecard, key performance indicator, performance dashboard

\begin{abstract}
Abstrak - XYZ Group telah melakukan ekspansi di berbagai bidang, yaitu retail, grocery, IT consultant, food \& beverages, shopping plaza, Japanese restaurant, e-wallet, e-commerce, dan ekspedisi. XYZ Group terus melakukan ekspansi sebagai tindakan untuk bertahan dan memenangkan persaingan. Oleh karena itu, Divisi Rekrutmen XYZ Group memegang peranan penting dalam aktivitas bisnis. Human Resource Scorecard menjadi metode yang sesuai untuk melakukan pengukuran kinerja pada divisi rekrutmen XYZ Group. Perancangan Human Resource Scorecard pada Divisi Rekrutmen XYZ Group menghasilkan 17 Key Performance Indicator (KPI), yaitu dua KPI perspektif financial, tiga KPI perspektif customer, delapan KPI perspektif operational, dan empat KPI perspektif strategic. Pengukuran kinerja dilakukan dengan melakukan pembobotan dilanjutkan pengukuran kinerja berdasarkan data yang diperlukan. Hasil pengukuran menunjukkan kinerja keseluruhan sebesar 3,534 yang berarti kinerja Divisi Rekrutmen XYZ Group tergolong baik. Kinerja perspektif financial mendapatkan nilai sebesar 2,5 (cukup baik), kinerja perspektf customer sebesar 3,831 (baik), kinerja perspektif operational sebesar 3,423 (baik), dan kinerja perspektif strategic sebesar 4 (baik). Berdasarkan KPI yang tidak mencapai target dibuat action plan. Selain action plan, dilakukan perncangan performance dashboard dan analisis cause and effect relationship setelah pengukuran.
\end{abstract}

Kata kunci: human resource scorecard, key performance indicator, performance dashboard

\section{PENDAHULUAN}

XYZ Group merupakan grup bisnis yang terdiri atas berbagai macam perusahaan yang saling berhubungan yaitu produksi, distributor dan ritel. XYZ Group masih terus melakukan ekspansi usaha untuk memperluas pasar ke seluruh Indonesia. Hal ini terlihat dari perkembangan XYZ Group memiliki unit bisnis yang bergerak di berbagai bidang lain selain minimarket XYZ yaitu; grocery, IT consultant, food and beverages, shopping plaza, bakery, Japanese restaurant, e-wallet, e- commerce, dan ekspedisi. Adanya ekspansi bisnis yang bergerak di bidang yang beragam membuat XYZ Group memerlukan inovasi-inovasi agar semua bisnis tersebut dapat bersaing di pasar sehingga XYZ Group membuat suatu program kerja untuk pelamar berpotensi sehingga mereka tertarik mendaftar di XYZ Group. Divisi rekrutmen XYZ Group memiliki tugas untuk melakukan perekrutan karyawan, memilih calon karyawan yang kompeten, dan menentukan posisi karyawan tersebut akan bekerja. Tugas divisi rekrutmen merupakan salah satu tugas penting departemen Human Resources \& Services dalam melakukan manajemen SDM yang baik. Oleh karena itu, XYZ Group berusaha 
memantau kinerja dari divisi rekrutmen XYZ Group sehingga peforma divisi rekrutmen tidak menurun pengukuran kinerja memiliki manfaat untuk manajemen perusahaan, tetapi pengukuran ini juga dapat membuat salah penafsiran sehingga perlu dilakukan dengan tepat (Atkinson, 1995).

Berdasarkan permasalahan yang ada maka rumusan masalah pada penelitian ini adalah perbaikan sistem pengukuran kinerja pada divisi rekrutmen XYZ Group pada departemen Human Resources \& Services yang masih berbasis aspek-aspek yang kurang menggambarkan kinerja divisi perusahaan. Padahal diperlukan pengukuran kinerja yang lebih rinci dan sesuai untuk divisi rekrutmen XYZ Group pada departemen Human Resources \& Services. Pengukuran yang sesuai untuk divisi rekrutmen XYZ Group adalah Human Resource Scorecard. Human Resource Scorecard adalah metode pengukuran yang lebih rinci daripada balanced scorecard dengan fokus utama pada peran sumber daya manusia dalam penciptaan nilai perusahaan (Becker et.al, 2001). Penelitian ini bertujuan untuk merancang dan melakukan pengukuran kinerja menggunakan Human Resource Scorecard. Hasil dari pengukuran Human Resource Scorecard akan ditampilkan dalam bentuk performance dashborad untuk memudahkan pembacaan hasil selain itu, dilakukan juga perancangan action plan terhadap KPI bermasalah. Berdasarkan tujuan penelitian tersebut diharapkan penelitian ini dapat membantu perusahaan dalam melakukan pengukuran kinerja yang sesuai untuk divisi rekrutmen XYZ Group.

Metode Human Resource Scorecard pada penelitian ini mengukur tingkat efisiensi sumber daya manusia dalam membantu perusahaan mencapai tujuan strategis seperti laba dan penghasilan. Menurut Becker et.al (2001) terdapat empat perspektif pada Human Resource Scorecard, yaitu:

1. Perspektif Keuangan (Financial)

Pada perspektif ini manajer SDM mengukur strategi yang digunakan serta implementasi pada manajemen sumber daya manusia memberikan kontribusi dalam segi keuangan perusahaan.

2. Perspektif Konsumen (Customer)

Pada perspektif konsumen, manajer bagian sumber daya mengidentifikasi pelanggan dan segmen pasar tempat unit bisnis akan bersaing. Perspektif konsumen mendorong manajer perusahaan untuk membahasakan strategi yang beorientasi pada konsumen dengan memanfaatkan manajemen sumber daya untuk memberikan keuntungan finansial masa depan.

3. Perspektif Operasional (Operational)

Pada perspektif operational, top level management perusahaan melakukan identifikasi operasi-operasi penting yang dilakukan oleh perusahaan.

4. Perspektif Strategis (Strategic)

Perspektif strategis memiliki fokus pada sistem dan strategi untuk pengembangan sumber daya manusia untuk kepentingan jangka panjang.

Dalam mendukung pengkuran kinerja dengan Human Resource Scoercard maka digunakan juga metode pembobotan AHP (Analytical Hiearachy Process). AHP merupakan metode pengambilan keputusan yang melibatkan sejumlah kriteria dan alternatif yang dipilih berdasarkan pertimbangan semua kriteria terkait (Saaty, 1983). Hal ini dikarenakan setiap perusahaan memiliki kecenderungan pembobotan yang berbeda-beda sehingga diperlukan pembobotan yang konsisten.

\section{METODE}

Penelitian diawali dengan melakukan pengumpulan data awal seputar visi, budaya dan aktivitas divisi rekrutmen XYZ Group. Berdasarkan data-data awal dilakukan analisis SWOT pada level XYZ Group sehingga didapatkan KPI untuk strategi pada level perusahaan. KPI pada 
level perusahaan akan diturunkan hingga level divisi rekrutmen XYZ Group menggunakan metode cascading process. Hasil dari proses cascading process berupa strategi dan KPI divisi rekrutmen XYZ Group diolah dalam strategy map untuk melihat hubungan antar strategi berdasarkan perspektif Human Resource Scorecard. Setelah pembuatan strategy map dilakukan pembobotan untuk masing-masing perspektif, strategi dan KPI. Pembobotan akan digunakan dalam melakukan perancangan pengukuran kinerja dengan metode Human Resource Scorecard berdasar KPI dan bobot yang sudah terbentuk. Hasil perancangan Human Resource Scorecard divisi rekrutmen XYZ Group akan digunakan untuk melakukan pengukuran kinerja divisi dengan data-data lainnya yang diperlukan. Hasil dari pengukuran kinerja akan dievaluasi yang mencakup analisis hasil setelah pengukuran, pemberian rancangan action plan untuk KPI yang bermasalah dan menampilkan hasil pengukuran dalam bentuk performance dashboard. Adapun kerangka berpikir pada penelitian ini adalah sebagai berikut:

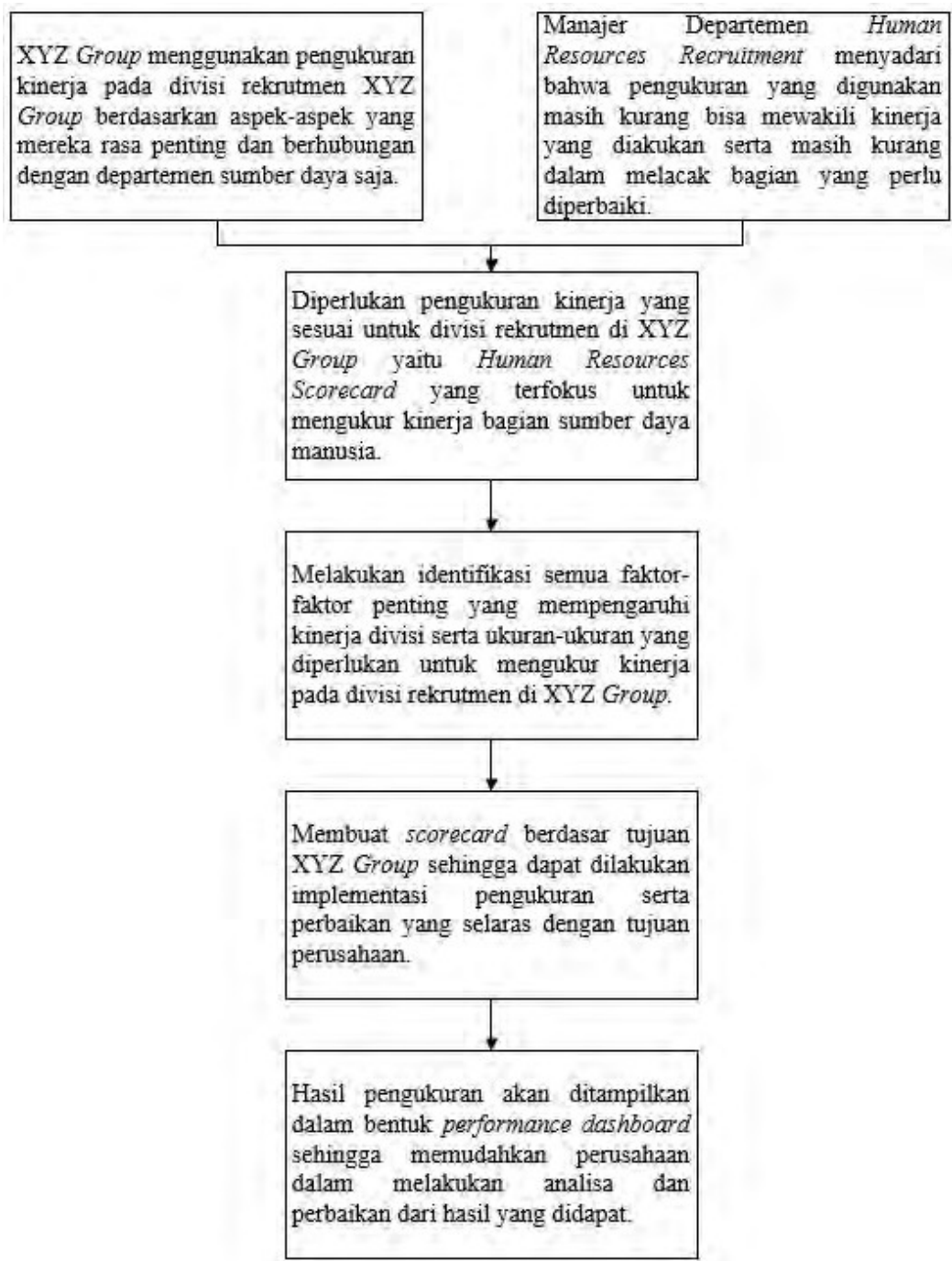

Gambar 1. Kerangka berpikir penelitian. 


\section{HASIL}

\section{Cascading Process Divisi Rekrutmen XYZ Group}

Pada penelitian ini dilakukan cacscading process serta analisis SWOT untuk mendapatkan strategi divisi rekrutmen XYZ Group. Proses penurunan dilakukan untuk menunjukan strategi divisi rekrutmen merupakan strategi untuk yang membantu perusahaan dalam mencapai tujuan. Berikut adalah cascading process yang dilakukan pada penelitian ini.

\section{Tabel 1}

Cascading Process

\begin{tabular}{|c|c|c|c|c|}
\hline $\begin{array}{c}\text { STRATEGI } \\
\text { PERUSAHAAN }\end{array}$ & $\begin{array}{l}\text { KPI } \\
\text { PERUSAHAAN }\end{array}$ & $\begin{array}{l}\text { STRATEGI } \\
\text { DEPARTEMEN }\end{array}$ & KPI DEPARTEMEN & $\begin{array}{l}\text { STRATEGI } \\
\text { DIVISI }\end{array}$ \\
\hline \multirow{4}{*}{$\begin{array}{l}\text { Membuka kantor } \\
\text { cabang dan toko ke } \\
\text { daerah-daerah } \\
\text { Indonesia yang } \\
\text { belum dimasuki } \\
\text { (SO1; CORP) }\end{array}$} & \multirow{4}{*}{$\begin{array}{l}\text { \%Peningkatan } \\
\text { jumlah toko }\end{array}$} & \multirow{4}{*}{$\begin{array}{l}\text { Meningkatkan jumlah } \\
\text { kegiatan rekrutmen } \\
\text { (SO1; } \\
\text { DEPT) }\end{array}$} & \multirow{4}{*}{$\begin{array}{l}\text { Pemenuhan PKtiap } \\
\text { bulan }\end{array}$} & $\begin{array}{l}\text { Melakukan } \\
\text { company } \\
\text { branding ke } \\
\text { kampus } \\
\text { mengenai } \\
\text { program } \\
\text { kerja XYZ } \\
\text { Group(WO2; } \\
\text { DIV) }\end{array}$ \\
\hline & & & & $\begin{array}{l}\text { Melakukan } \\
\text { seleksi event } \\
\text { rekrutmen } \\
\text { yang tidak } \\
\text { member } \\
\text { hasil baik } \\
\text { (WT2; DIV) }\end{array}$ \\
\hline & & & & $\begin{array}{l}\text { Analisis } \\
\text { sumber } \\
\text { penyedia } \\
\text { pelamar } \\
\text { (WT1; DIV) }\end{array}$ \\
\hline & & & & $\begin{array}{l}\text { Meningkatk } \\
\text { an kegiatan } \\
\text { rekrutmen } \\
\text { MDP dan ISS } \\
\text { (SO1; DIV) }\end{array}$ \\
\hline \multirow[b]{2}{*}{$\begin{array}{l}\text { Menggunakan } \\
\text { media sosial untuk } \\
\text { memasarkan } \\
\text { keunggulan } \\
\text { perusahaan (SO2; } \\
\text { CORP) }\end{array}$} & \multirow[b]{2}{*}{$\begin{array}{l}\text { \%Brand } \\
\text { awareness }\end{array}$} & \multirow[b]{2}{*}{$\begin{array}{l}\text { Meningkatkan promosi } \\
\text { program perusahaan } \\
\text { (SO2; DEPT) }\end{array}$} & \multirow[b]{2}{*}{$\begin{array}{l}\text { Banyak lamaran } \\
\text { yang masuk ke } \\
\text { perusahaan }\end{array}$} & $\begin{array}{l}\text { Melakukan } \\
\text { pencarian } \\
\text { kandidat } \\
\text { dari sumber } \\
\text { penyedia } \\
\text { karyawan } \\
\text { (SO2; DIV) }\end{array}$ \\
\hline & & & & $\begin{array}{l}\text { Melakukan } \\
\text { publikasi } \\
\text { mengenai } \\
\text { event } \\
\text { rekrutmen } \\
\text { dan } \\
\text { pengalaman } \\
\text { berkarir di } \\
\text { XYZ Group } \\
\text { (ST2; DIV) }\end{array}$ \\
\hline
\end{tabular}




\begin{tabular}{|c|c|c|c|c|}
\hline $\begin{array}{l}\text { Bekerja sama } \\
\text { dengan pihak- } \\
\text { pihak eksternal } \\
\text { untuk melakukan } \\
\text { pekerjaan yang } \\
\text { spesifik (SO3; } \\
\text { CORP) }\end{array}$ & $\begin{array}{l}\text { \%Efektivitas } \\
\text { kinerjapihak } \\
\text { ekstrenal }\end{array}$ & $\begin{array}{l}\text { Bekerja sama dengan } \\
\text { pihak-pihakeksternal } \\
\text { untuk membantu } \\
\text { manajemen SDM (SO3; } \\
\text { DEPT) }\end{array}$ & $\begin{array}{l}\text { \%Efektifitas kerja } \\
\text { sama yang } \\
\text { dilakukan }\end{array}$ & $\begin{array}{l}\text { Bekerja } \\
\text { sama } \\
\text { dengan } \\
\text { pihak } \\
\text { eksternal } \\
\text { untuk } \\
\text { membantu } \\
\text { proses } \\
\text { kegiatan } \\
\text { rekrutmen } \\
\text { (WO3; } \\
\text { DIV) }\end{array}$ \\
\hline $\begin{array}{l}\text { Memakai teknologi } \\
\text { sebagai alternatif } \\
\text { pengganti fasilitas } \\
\text { tertentu } \\
\text { (WO 2; CORP) }\end{array}$ & $\begin{array}{l}\text { \%Efektifitas } \\
\text { anggaran } \\
\text { fasilitas } \\
\text { perusahaan }\end{array}$ & $\begin{array}{l}\text { Memakai teknologi } \\
\text { sebagai alternatif } \\
\text { fasilitas untuk training } \\
\text { ataupun rerkutmen } \\
\text { (WO2; DEPT) }\end{array}$ & $\begin{array}{l}\text { \%Efektifitas } \\
\text { anggaran fasilitas } \\
\text { departemen } \\
\text { Human Resources } \\
\text { \& } \\
\text { Services }\end{array}$ & $\begin{array}{l}\text { Memakai } \\
\text { teknologi } \\
\text { sebagai } \\
\text { alternatif } \\
\text { proseskerja } \\
\text { rekrutmen } \\
\text { (WO1; DIV) }\end{array}$ \\
\hline $\begin{array}{l}\text { Memakai teknologi } \\
\text { sebagaialternatif } \\
\text { pengganti fasilitas } \\
\text { tertentu } \\
\text { (WO 2; CORP) }\end{array}$ & $\begin{array}{l}\text { \%Efektifitas } \\
\text { anggaran } \\
\text { fasilitas } \\
\text { perusahaan }\end{array}$ & $\begin{array}{l}\text { Memakai teknologi } \\
\text { sebagai alternatif } \\
\text { fasilitas untuk training } \\
\text { ataupun rerkutmen } \\
\text { (WO2; DEPT) }\end{array}$ & $\begin{array}{l}\text { \%Efektifitas } \\
\text { anggaran fasilitas } \\
\text { departemen } \\
\text { Human Resources } \\
\text { \& } \\
\text { Services }\end{array}$ & $\begin{array}{l}\text { Memakai } \\
\text { teknologi } \\
\text { sebagai } \\
\text { alternatif } \\
\text { proseskerja } \\
\text { rekrutmen } \\
\text { (W01; DIV) }\end{array}$ \\
\hline \multirow{2}{*}{$\begin{array}{l}\text { Memberikan } \\
\text { pelatihan- } \\
\text { pelatihan hardskill } \\
\text { bagi pegawai } \\
\text { perusahaan (WO4; } \\
\text { CORP) }\end{array}$} & \multirow{2}{*}{$\begin{array}{l}\text { \%Peforma } \\
\text { Pegawai }\end{array}$} & $\begin{array}{l}\text { Melakukan tes seleksi } \\
\text { sesuai kebutuhan } \\
\text { departemen(SO5; DEPT) }\end{array}$ & $\begin{array}{l}\text { Rata-rata skor } \\
\text { kompetensi } \\
\text { karyawan }\end{array}$ & $\begin{array}{l}\text { Melakukan } \\
\text { rerkutmen } \\
\text { berdasarkan } \\
\text { program } \\
\text { kerja dan } \\
\text { permintaan } \\
\text { tiap } \\
\text { departemen } \\
\text { (ST1; DIV) }\end{array}$ \\
\hline & & $\begin{array}{l}\text { Membuat program } \\
\text { magang dengan } \\
\text { menyesuaikan ketentuan } \\
\text { kurikulum yang } \\
\text { dibutuhkan(WO4; } \\
\text { DEPT) }\end{array}$ & $\begin{array}{l}\text { Banyak anak } \\
\text { magang yang } \\
\text { mendaftar tiap } \\
\text { bulan }\end{array}$ & $\begin{array}{l}\text { Bekerja } \\
\text { sama } \\
\text { dengan } \\
\text { kampus- } \\
\text { kampus } \\
\text { yang ada di } \\
\text { Indonesia } \\
\text { (SO3; DIV) }\end{array}$ \\
\hline $\begin{array}{l}\text { Memakai teknologi } \\
\text { sebagaialternatif } \\
\text { pengganti } \\
\text { fasilitas tertentu } \\
\text { (WO 2; CORP) }\end{array}$ & $\begin{array}{l}\text { \%Efektifitas } \\
\text { anggaran } \\
\text { fasilitas } \\
\text { perusahaan }\end{array}$ & $\begin{array}{l}\text { Memakai teknologi } \\
\text { sebagai alternatif } \\
\text { fasilitas untuk training } \\
\text { ataupun rerkutmen } \\
\text { (WO2; DEPT) }\end{array}$ & $\begin{array}{l}\text { \%Efektifitas } \\
\text { anggaran fasilitas } \\
\text { departemen } \\
\text { Human } \\
\text { Resources \& } \\
\text { Services }\end{array}$ & $\begin{array}{l}\text { Memakai } \\
\text { teknologi } \\
\text { sebagai } \\
\text { alternatif } \\
\text { proses } \\
\text { kerja } \\
\text { rekrutmen } \\
\text { (WO1; DIV) }\end{array}$ \\
\hline
\end{tabular}




\section{Pembuatan Key Performance Indicator (KPI)}

Berdasarkan strategi yang telah terbentuk maka dilakukan pembuatan KPI untuk masing- masing strategi berdasarkan perspektif Human Resource Scorecard. Terdapat dua jenis KPI yaitu leading indicator yang memperngaruhi lagging indicator. Berikut adalah KPI dari strategi divisi rekrutmen XYZ Group berdasarkan perspektif Human Resource Scorecard:

Tabel 2

KPI Divisi Rekrutmen XYZ Group

\begin{tabular}{|c|c|c|c|c|c|}
\hline \multirow{2}{*}{ Perspektif } & \multirow{2}{*}{ Strategi Divisi } & \multicolumn{4}{|c|}{ Ukuran Human Resource Scorecard } \\
\hline & & & Leading Indicator & & Lagging Indicator \\
\hline \multirow[t]{2}{*}{ Financial } & $\begin{array}{l}\text { Bekerja sama dengan } \\
\text { pihakeksternal untuk } \\
\text { membantu proses } \\
\text { kegiatan rekrutmen }\end{array}$ & & & $\mathrm{F}-1.1$ & $\begin{array}{l}\text { \%Realisasi } \\
\text { anggaran job } \\
\text { portal }\end{array}$ \\
\hline & $\begin{array}{l}\text { Melakukan seleksi event } \\
\text { rekrutmen yang tidak } \\
\text { memberi hasil baik }\end{array}$ & & & $\mathrm{F}-2.1$ & Man power cost \\
\hline \multirow{3}{*}{ Customer } & $\begin{array}{l}\text { Melakukan rekrutmen } \\
\text { berdasarkan program } \\
\text { kerja }\end{array}$ & & & C-1.1 & $\begin{array}{l}\text { \%Service level } \\
\text { pemenuhan PK } \\
\text { (lead time PK) }\end{array}$ \\
\hline & $\begin{array}{l}\text { Dan permintaan tiap } \\
\text { departemen }\end{array}$ & & & C-2.1 & $\begin{array}{l}\text { \%Karyawan } \\
\text { bermasalah }\end{array}$ \\
\hline & $\begin{array}{l}\text { Melakukan publikasi } \\
\text { mengenai event } \\
\text { rekrutmen dan } \\
\text { pengalaman berkarir di } \\
\text { XYZ Group }\end{array}$ & & & C-3.1 & $\begin{array}{l}\text { Kesesuaian } \\
\text { jumlah dan jenis } \\
\text { publikasi } \\
\text { berdasarkan } \\
\text { karakteristik } \\
\text { prodi dan } \\
\text { universitas }\end{array}$ \\
\hline \multirow{2}{*}{ Operational } & $\begin{array}{l}\text { Melakukan company } \\
\text { branding ke kampus } \\
\text { mengenai berkarir XYZ } \\
\text { Group }\end{array}$ & 0-1.1 & $\begin{array}{l}\text { Tingkat partisipan } \\
\text { event (company } \\
\text { branding) }\end{array}$ & 0-1.2 & $\begin{array}{l}\text { \%Banyak } \\
\text { pendaftar dari } \\
\text { event (company } \\
\text { branding) }\end{array}$ \\
\hline & $\begin{array}{l}\text { Melakukan karyawan } \\
\text { berpotensi / skill khusus } \\
\text { sesuai kebutuhan } \\
\text { perusahaan melaui HRIS }\end{array}$ & & & $0-2.1$ & $\begin{array}{l}\text { Jumlah kandidat } \\
\text { pending yang } \\
\text { belum menjalani } \\
\text { psikotes }\end{array}$ \\
\hline
\end{tabular}


Melakukan pencarian kandidat dari sumber penyedia pelamar
Kesesuaian jumlah

dan jenis event

0-3.1 berdasarkan

karakteristik prodi

$0-3.2$

Banyak CV OK

yang masuk
Memakai teknologi

sebagai alternatif

komunikasi dengan

relasi kerja rekrutmen

\begin{tabular}{|c|c|c|c|c|}
\hline & & \%Intern yang & & Banyak karyawan \\
\hline $\begin{array}{l}\text { Meningkatkan kegiatan } \\
\text { rekrutmen MDP dan ISS }\end{array}$ & $0-5.1$ & $\begin{array}{l}\text { masuk sesuai } \\
\text { dengan PK yang } \\
\text { jatuh tempo }\end{array}$ & $0-5.2$ & $\begin{array}{l}\text { MDP dan ISS yang } \\
\text { didapat tiap } \\
\text { bulan dari event }\end{array}$ \\
\hline
\end{tabular}

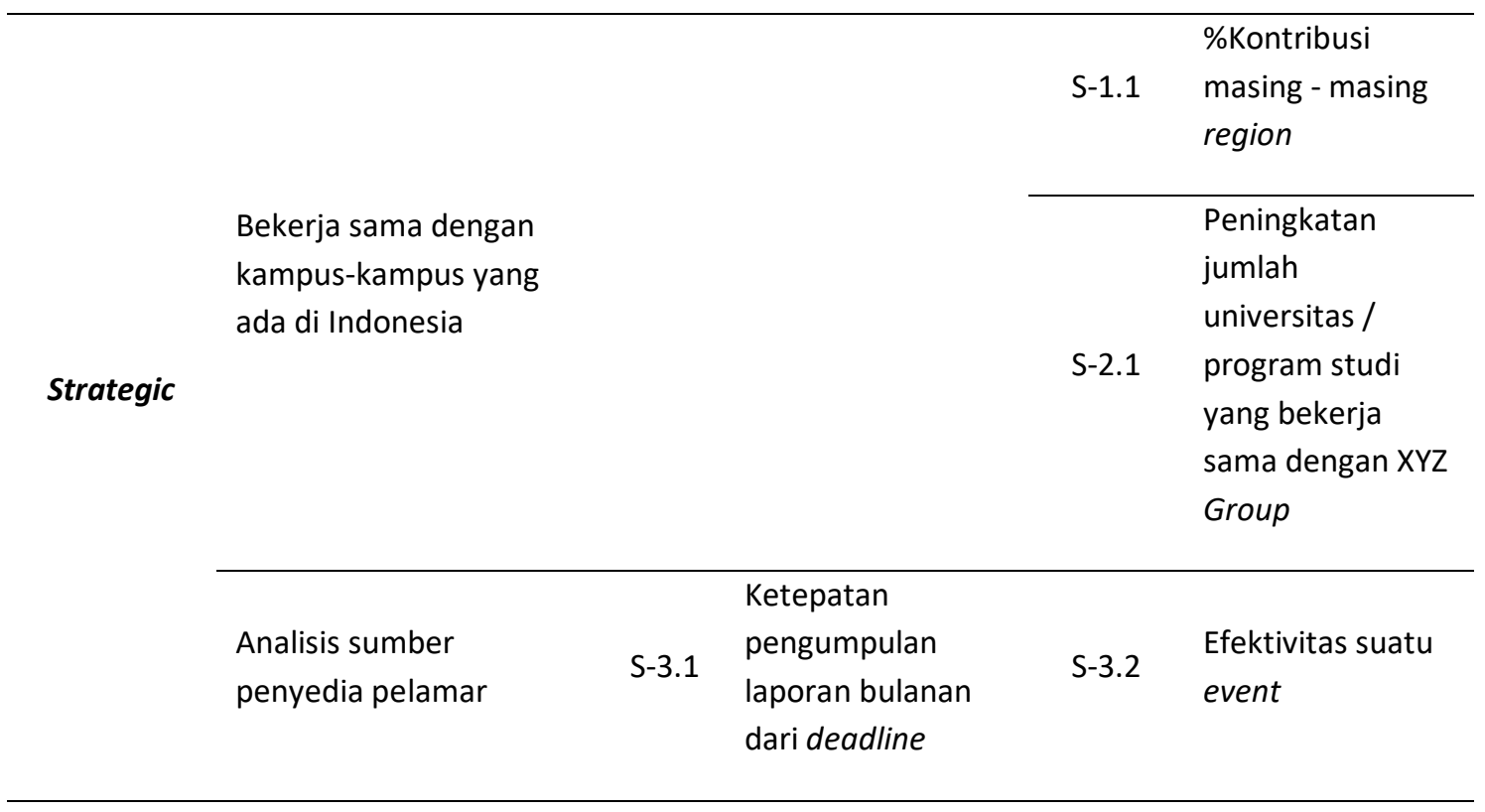

\section{Pembobotan dengan AHP}

Dalam melakukan pengukuran menggunakan Human Resource Scorecard maka dilakukan pembobotan terlebih dahulu menggunaka metode AHP. Pada penelitian ini digunakan bantuan software yaitu Expert Choice11. Data berikut ini merupakan rekap hasil pembobotan yang telah dilakukan:

Tabel 3

Rekap Hasil Pembobotan

\begin{tabular}{lllllll}
\hline Perspektif & $\begin{array}{l}\text { Bobot } \\
\text { Perspektif }\end{array}$ & Strategi & $\begin{array}{l}\text { Bobot } \\
\text { Strategi }\end{array}$ & KPI & Bobot KPI & $\begin{array}{l}\text { Bobot } \\
\text { Global }\end{array}$ \\
\hline Finansial & 0,240 & $\begin{array}{l}\text { Bekerja sama } \\
\text { dengan pihak } \\
\text { eksternal untuk } \\
\text { membantu proses }\end{array}$ & 0,250 & $\begin{array}{l}\text { \%Realisasi } \\
\text { anggaran job } \\
\text { portal }\end{array}$ & 1,000 & 0,060 \\
\hline
\end{tabular}




\begin{tabular}{|c|c|c|c|c|c|c|}
\hline & & $\begin{array}{l}\text { kegiatan } \\
\text { rekrutmen }\end{array}$ & & & & \\
\hline & & $\begin{array}{l}\text { Melakukan } \\
\text { selekksi event } \\
\text { rekrutmen yang } \\
\text { tidak memberi } \\
\text { hasil baik }\end{array}$ & 0,750 & $\begin{array}{l}\text { Efektivitas } \\
\text { suatu } \\
\text { event }\end{array}$ & 1,000 & 0,180 \\
\hline \multirow{3}{*}{ Customer } & \multirow{3}{*}{0,314} & \multirow{2}{*}{$\begin{array}{l}\text { Melakukan } \\
\text { rekrutmen } \\
\text { berdasarkan } \\
\text { program kerja } \\
\text { dan permintaan } \\
\text { tiap departemen }\end{array}$} & \multirow[t]{2}{*}{0,833} & $\begin{array}{l}\text { \%Service level } \\
\text { pemenuhan } \\
\text { PK (lead time } \\
\text { PK) }\end{array}$ & 0,600 & 0,157 \\
\hline & & & & $\begin{array}{l}\text { \%Karyawan } \\
\text { bermasalah }\end{array}$ & 0,400 & 0,105 \\
\hline & & $\begin{array}{l}\text { Melakukan } \\
\text { publikasi } \\
\text { mengenai event } \\
\text { rekrutmen dan } \\
\text { pengalaman } \\
\text { berkarir di XYZ } \\
\text { Group }\end{array}$ & 0,167 & $\begin{array}{l}\text { Kesesuaian } \\
\text { jumlah dan } \\
\text { jenis publikasi } \\
\text { berdasarkan } \\
\text { karakteristik } \\
\text { prodi dan } \\
\text { universitas }\end{array}$ & 1,000 & 0,052 \\
\hline \multirow{6}{*}{$\begin{array}{l}\text { Operation } \\
\text { al }\end{array}$} & \multirow{5}{*}{0,258} & \multirow{2}{*}{$\begin{array}{l}\text { Melakukan } \\
\text { company } \\
\text { branding ke } \\
\text { kampus mengenai } \\
\text { berkarir di XYZ } \\
\text { Group }\end{array}$} & \multirow[t]{2}{*}{0,107} & $\begin{array}{l}\text { Tingkat } \\
\text { partisipasi } \\
\text { event } \\
\text { (company } \\
\text { branding) } \\
\end{array}$ & 0,400 & 0,011 \\
\hline & & & & $\begin{array}{l}\text { Banyak } \\
\text { pendaftar dari } \\
\text { event } \\
\text { (company } \\
\text { branding) }\end{array}$ & 0,600 & 0,017 \\
\hline & & $\begin{array}{l}\text { Melakukan } \\
\text { tracking } \\
\text { karyawan } \\
\text { berpotensi / skill } \\
\text { khusus sesuai } \\
\text { kebutuhan } \\
\text { perusahaan } \\
\text { melaui HRIS }\end{array}$ & 0,185 & $\begin{array}{l}\text { Jumlah } \\
\text { kandidat } \\
\text { pending yang } \\
\text { belum } \\
\text { psikotes }\end{array}$ & 1,000 & 0,048 \\
\hline & & \multirow[t]{2}{*}{$\begin{array}{l}\text { Melakukan } \\
\text { pencarian } \\
\text { kandidat dari } \\
\text { sumber } \\
\text { penyedia } \\
\text { karyawan }\end{array}$} & \multirow[t]{2}{*}{0,245} & $\begin{array}{l}\text { Kesesuaian } \\
\text { jumlah dan } \\
\text { jenis event } \\
\text { berdasarkan } \\
\text { karakteristik } \\
\text { prodi dan } \\
\text { universitas } \\
\end{array}$ & 0,500 & 0,032 \\
\hline & & & & $\begin{array}{l}\text { Banyak CV OK } \\
\text { yang masuk }\end{array}$ & 0,500 & 0,032 \\
\hline & & $\begin{array}{l}\text { Memakai } \\
\text { teknologi sebagai } \\
\text { alternatif proses } \\
\text { kerja rekrutmen }\end{array}$ & 0,141 & $\begin{array}{l}\text { lead time } \\
\text { proses seleksi } \\
\text { sampai } \\
\text { dengan }\end{array}$ & 1,000 & 0,036 \\
\hline
\end{tabular}




\begin{tabular}{|c|c|c|c|c|c|c|}
\hline & & & & $\begin{array}{l}\text { submit } \\
\text { interview } \\
\text { akhir }\end{array}$ & & \\
\hline & & \multirow{2}{*}{$\begin{array}{l}\text { Meningkatkan } \\
\text { kegiatan } \\
\text { rekrutmen MDP } \\
\text { dan ISS }\end{array}$} & \multirow[t]{2}{*}{0,323} & $\begin{array}{l}\text { \%Intern yang } \\
\text { masuk sesuai } \\
\text { dengan PK } \\
\text { yang jatuh } \\
\text { tempo }\end{array}$ & 0,500 & 0,042 \\
\hline & & & & $\begin{array}{l}\text { Banyak } \\
\text { karyawan } \\
\text { MDP dan ISS } \\
\text { yang } \\
\end{array}$ & 0,500 & 0,042 \\
\hline \multirow{4}{*}{ Strategic } & \multirow{4}{*}{0,189} & \multirow[b]{2}{*}{$\begin{array}{l}\text { Bekerja sama } \\
\text { dengan kampus- } \\
\text { kampus yang ada } \\
\text { di Indonesia }\end{array}$} & \multirow[b]{2}{*}{0,200} & $\begin{array}{l}\text { \%Kontribusi } \\
\text { masing- } \\
\text { masing region }\end{array}$ & 0,750 & 0,028 \\
\hline & & & & $\begin{array}{l}\text { Peningkatan } \\
\text { jumlah } \\
\text { universitas / } \\
\text { program studi } \\
\text { kampus yang } \\
\text { bekerja sama } \\
\text { dengan XYZ } \\
\text { Group }\end{array}$ & 0,250 & 0,009 \\
\hline & & \multirow[t]{2}{*}{$\begin{array}{l}\text { Analisis sumber } \\
\text { penyedia pelamar }\end{array}$} & \multirow[t]{2}{*}{0,800} & $\begin{array}{l}\text { Ketepatan } \\
\text { pengumpulan } \\
\text { laporan } \\
\text { bulanan dari } \\
\text { deadline }\end{array}$ & 0,167 & 0,025 \\
\hline & & & & $\begin{array}{l}\text { man power } \\
\text { cost }\end{array}$ & 0,833 & 0,126 \\
\hline
\end{tabular}

\section{Pengukuran Kinerja Divisi Rekrutmen XYZ Group}

KPI yang telah dirancang dan dibobotkan maka dilakukan pengukuran untuk masingmasing KPI. Pengukuran KPI ini akan menghasilkan kinerja untuk masing-masing KPI, perspektif dan kinerja keseluruhan. Pengukuran yang dilakukan menggunakan data pada bulan September 2019. Berikut adalah hasil pengukuran divisi rekrutmen XYZ Group:

Tabel 4

Hasil Pengukuran Kinerja Divisi Rekrutmen XYZ Group

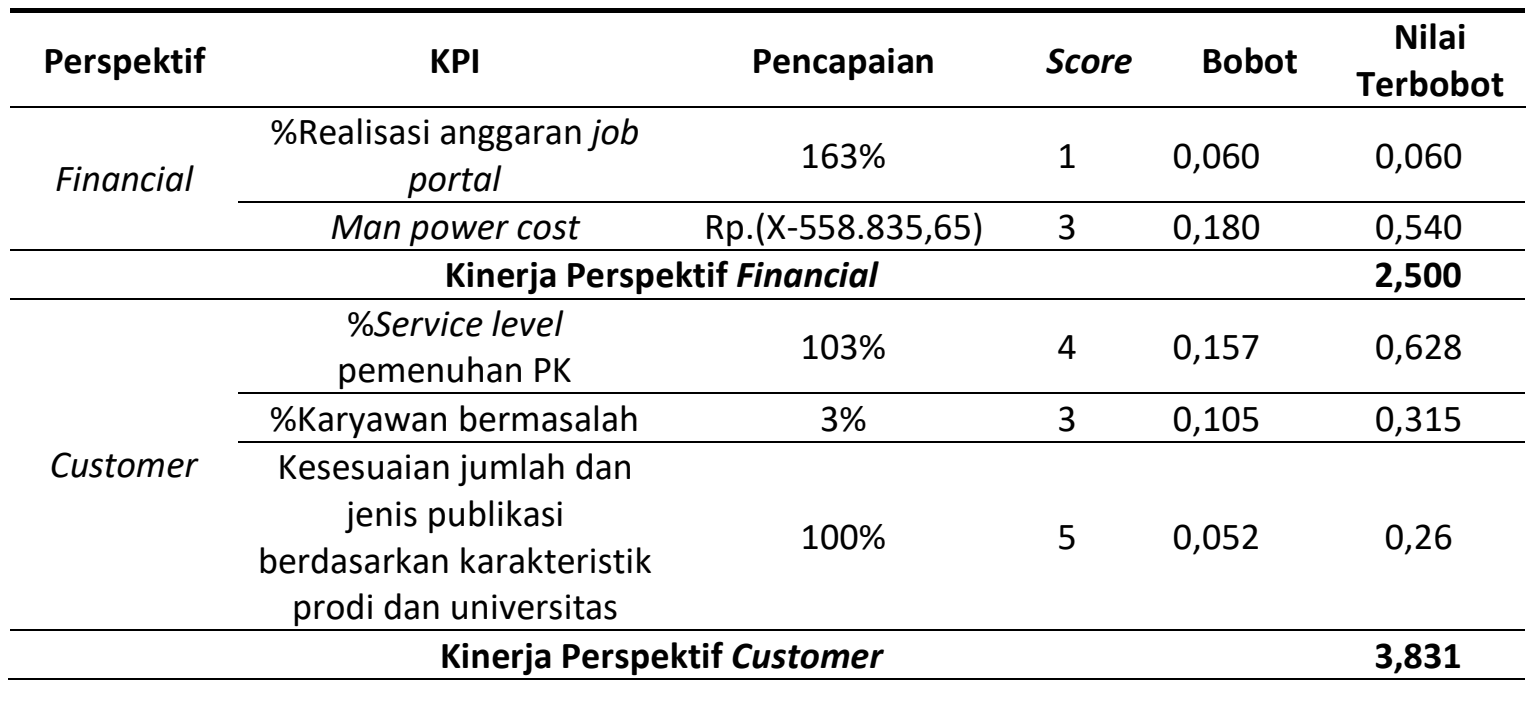




\begin{tabular}{|c|c|c|c|c|c|}
\hline & $\begin{array}{l}\text { Tingkat partisipan event } \\
\text { (company branding) }\end{array}$ & 50 & 5 & 0,011 & 0,055 \\
\hline & $\begin{array}{c}\text { \%banyak pendaftar dari } \\
\text { event (company } \\
\text { branding) }\end{array}$ & $30 \%$ & 1 & 0,017 & 0,017 \\
\hline & $\begin{array}{l}\text { Jumlah kandidat pending } \\
\text { yang belum psikotes }\end{array}$ & $(X-31)$ & 4 & 0,048 & 0,192 \\
\hline \multirow[t]{6}{*}{ Operational } & $\begin{array}{c}\text { Kesesuaian jumlah dan } \\
\text { jenis event berdasarkan } \\
\text { karakteristik prodi dan } \\
\text { universitas }\end{array}$ & $100 \%$ & 5 & 0,032 & 0,160 \\
\hline & Banyak CV OK & $(X+246)$ & 5 & 0,032 & 0,160 \\
\hline & $\begin{array}{l}\text { Lead time seleksi sampai } \\
\text { submit interview akhir }\end{array}$ & 4 & 5 & 0,036 & 0,180 \\
\hline & $\begin{array}{l}\text { \%Intern yang masuk } \\
\text { sesuai PK jatuh tempo }\end{array}$ & $8 \%$ & 1 & 0,042 & 0,042 \\
\hline & $\begin{array}{c}\text { Banyak karyawan MDP } \\
\text { dan ISS yang didapat tiap } \\
\text { bulan dari event }\end{array}$ & $(\mathrm{Y}-1)$ & 2 & 0,042 & 0,084 \\
\hline & \multicolumn{3}{|c|}{ Kinerja Perspektif Operational } & & 3,423 \\
\hline \multirow[t]{6}{*}{ Strategic } & $\begin{array}{l}\text { \%Kontribusi masing- } \\
\text { masing region }\end{array}$ & $103 \%$ & 3 & 0,028 & 0,084 \\
\hline & $\begin{array}{c}\text { Peningkatan universitas/ } \\
\text { progam studi yang } \\
\text { bekerja sama dengan XYZ } \\
\text { Group }\end{array}$ & 8 & 3 & 0,009 & 0,027 \\
\hline & $\begin{array}{c}\text { Ketepatan pengumpulan } \\
\text { laporan bulanan dari } \\
\text { deadline }\end{array}$ & $\mathrm{H}$ & 3 & 0,025 & 0,075 \\
\hline & Efektivitas suatu event & Rp.(X-900.248,69),- & 5 & 0,126 & 0,630 \\
\hline & \multicolumn{2}{|c|}{ Kinerja Perspektif Strategic } & & & 4,340 \\
\hline & \multicolumn{2}{|c|}{ Kinerja Keseluruhan } & & & 3,506 \\
\hline
\end{tabular}

Dari hasil pengukuran terlihat bahwa kinerja keseluruhan sebesar 3,534 yang berarti kinerja Divisi Rekrutmen XYZ Group tergolong baik. Kinerja perspektif financial mendapatkan nilai sebesar 2,5 (cukup baik), kinerja perspektf customer sebesar 3,831 (baik), kinerja perspektif operational sebesar 3,423 (baik), dan kinerja perspektif strategic sebesar 4 (baik). Meskpiun kinerja divisi rekrutmen XYZ Group tergolong baik tetapi terdapat beberapa KPI yang belum mencapai standar sehingga kinerja divisi rekrutmen XYZ Group belum maksimal. Oleh karena itu, pada penelitian ini dilakukan perancangan perbaikan untuk KPI yang bermasalah.

\section{Perancangan Action Plan}

Hasil pengukuran untuk masing-masing KPI divisi rekrutmen XYZ Group menunjukkan terdapat beberapa KPI bermasalah sehingga dilakukan rancangan perbaikan berupa action plan yang dapat dilakukan perusahaan. Berikut adalah rancangan perbaikan bagi KPI bermasalah divisi rekrutmen XYZ Group: 
Tabel 5

Rancangan Perbaikan

\begin{tabular}{|c|c|c|c|c|}
\hline No. & KPI Bermasalah & Penyebab & $\begin{array}{c}\text { Inisiatif } \\
\text { Perbaikan }\end{array}$ & Action Plan \\
\hline \multirow[b]{2}{*}{1} & \multirow{2}{*}{$\begin{array}{c}\text { \%Realisasi } \\
\text { anggaran job } \\
\text { portal }\end{array}$} & \multirow{2}{*}{$\begin{array}{c}\text { Adanya fitur baru yang } \\
\text { ditawarkan oleh pihak } \\
\text { eksternal yaitu } \\
\text { lamaran yang masuk } \\
\text { dapat disambungkan } \\
\text { dengan website } \\
\text { perusahaan sehingga } \\
\text { muncul biaya melebihi } \\
\text { anggaran. }\end{array}$} & \multirow{2}{*}{$\begin{array}{c}\text { Membuat } \\
\text { anggaran yang } \\
\text { sesuai }\end{array}$} & $\begin{array}{c}\text { Melakukan listing } \\
\text { kebutuhan posting } \\
\text { lowongan pekerjaan }\end{array}$ \\
\hline & & & & $\begin{array}{l}\text { Melakukan } \\
\text { forecasting harga } \\
\text { layanan job portal }\end{array}$ \\
\hline \multirow[b]{2}{*}{2} & \multirow{2}{*}{$\begin{array}{c}\text { Banyak } \\
\text { pendaftar dari } \\
\text { event (company } \\
\text { branding) }\end{array}$} & \multirow{2}{*}{$\begin{array}{c}\text { Pada kegiatan } \\
\text { company branding } \\
\text { tidak berhasil menarik } \\
\text { pendaftar sesuai } \\
\text { target karena acara } \\
\text { tersebut bersifat wajib } \\
\text { sehingga mahasisawa } \\
\text { datang bukan karena } \\
\text { menginginkan tetapi } \\
\text { karena terpaksa. }\end{array}$} & $\begin{array}{c}\text { Melakukan initial } \\
\text { company } \\
\text { branding }\end{array}$ & $\begin{array}{l}\text { Melakukan publikasi } \\
\text { mengenai event- } \\
\text { event yang akan } \\
\text { datang sebelum hari } \\
\text { acara. }\end{array}$ \\
\hline & & & $\begin{array}{c}\text { Melakukan } \\
\text { publikasi } \\
\text { dengan menarik }\end{array}$ & $\begin{array}{c}\text { Membawa } \\
\text { perusahaan yang } \\
\text { tergabung dengan } \\
\text { XYZ Group atau } \\
\text { alumni untuk } \\
\text { publikasi }\end{array}$ \\
\hline \multirow[t]{2}{*}{3} & \multirow{2}{*}{$\begin{array}{l}\text { Banyak karyawan } \\
\text { MDP dan ISS } \\
\text { yang didapat tiap } \\
\text { bulan dari event }\end{array}$} & \multirow{2}{*}{$\begin{array}{l}\text { Adanya ikatan dinas } \\
\text { untuk penempatan } \\
\text { nasioanal menjadi } \\
\text { kendala karena } \\
\text { pelamar cenderung } \\
\text { mengiginkan } \\
\text { penempatan pada } \\
\text { area tertentu saja. }\end{array}$} & \multirow{2}{*}{$\begin{array}{l}\text { Menjelaskan } \\
\text { kelebihan } \\
\text { program } \\
\text { kerja XYZ Group }\end{array}$} & $\begin{array}{l}\text { Menggunakan media } \\
\text { sosial yang dimiliki } \\
\text { untuk publikasi } \\
\text { mengenai program } \\
\text { karir XYZ Group }\end{array}$ \\
\hline & & & & $\begin{array}{l}\text { Membuat video } \\
\text { testimoni program } \\
\text { karir XYZ Group }\end{array}$ \\
\hline
\end{tabular}

\section{Perancangan Performance Dashboard}

Dalam memudahkan pembacaan hasil pegukuran maka digunakan performance dashboard. Perancangan performance dashboard dibantu dengan bantuan software PowerBI. Tujuan perancangan dashboard adalah membantu perusahaan mengukur proses yang sudah berjalan secara cepat dalam hal waktu, melakukan monitor kinerja serta bahan evaluasi masa mendatang. Berdasarkan indikator yang sudah ada, peneliti menampilkan indikator tertentu untuk membuat performance dashboard yang efektif dan efisien. Oleh karena itu, peneliti melakukan seleksi KPI dengan bantuan pairwise comparison AHP serta berdasarkan kebutuhan divisi rekrutmen XYZ Group 


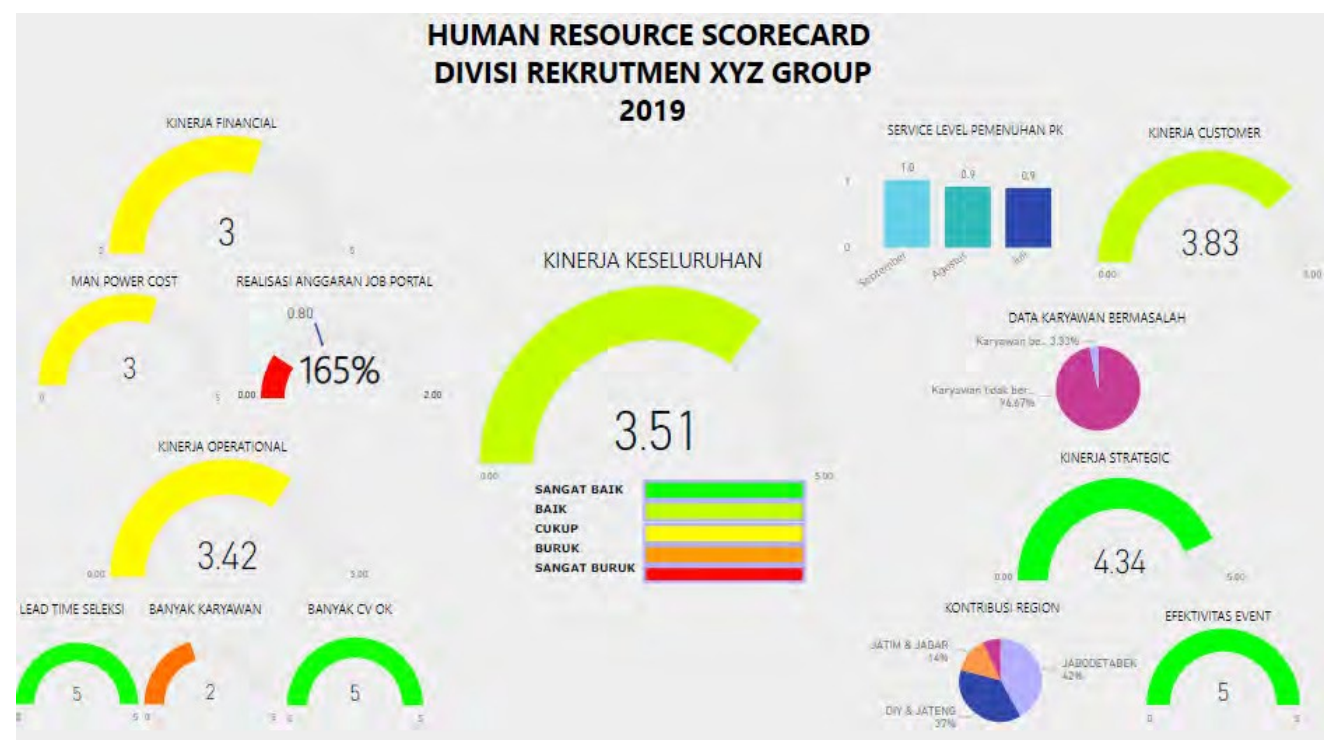

Gambar 2. Performance dashboard divisi rekrutmen.

Diskusi

Penelitian mengenai pengukuran kinerja suatu perusahaan telah dilakukan oleh peneliti lainnya. Berikut ini adalah posisi penelitian pada tugas akhir ini jika dibandingkan dengan penelitian yang relevan sebelumnya.

Tabel 6

Posisi Penelitian

\begin{tabular}{|c|c|c|c|c|c|c|c|}
\hline \multirow[b]{2}{*}{ No } & \multirow[b]{2}{*}{ Nama } & \multirow[b]{2}{*}{ Tahun } & \multirow[b]{2}{*}{ Judul } & \multicolumn{4}{|c|}{ Karakteristik } \\
\hline & & & & Metode & Objek Penelitian & Pembuatan KPI & $\begin{array}{c}\text { Analisis Strategi } \\
\text { \& KPI } \\
\end{array}$ \\
\hline 1 & Winda Krisianti & 2003 & $\begin{array}{l}\text { Analisis dan Perancangan } \\
\text { Human Resources Scorecard } \\
\text { Pada Divisi HRD di } \\
\text { PT.Panggong Electric } \\
\text { Corporation }\end{array}$ & $\begin{array}{l}\text { HR Scorecard (empat } \\
\text { perspektif Balanced } \\
\text { Scorecard, financial, } \\
\text { customer, internal } \\
\text { bussiness process, dan } \\
\text { learning and growth) }\end{array}$ & $\begin{array}{l}\text { Perusahaan produsen alat } \\
\text { elektronik }\end{array}$ & $\begin{array}{l}\text { Berdasarkan hasil } \\
\text { maping dari visi, misi } \\
\text { dan strategi pervsahaan } \\
\text { serta SWOT }\end{array}$ & Tidak ada \\
\hline 3 & $\begin{array}{l}\text { Erlinda Muslim dan Frinda } \\
\text { Firania }\end{array}$ & 2016 & $\begin{array}{l}\text { Designing The Human Resource } \\
\text { Scoercard As A Perdormance } \\
\text { Measurement of Human } \\
\text { Resource. }\end{array}$ & $\begin{array}{l}\text { HR Scorecard (empat } \\
\text { perspektif, financial, } \\
\text { customer, operational, } \\
\text { dan strategic) }\end{array}$ & Perusahaan MIGAS & $\begin{array}{l}\text { Berdasarkan hasil } \\
\text { maping dari visi, misi } \\
\text { dan strategi perusahaan }\end{array}$ & Tidak ada \\
\hline & Penelitian Ini & 2019 & $\begin{array}{l}\text { Perancangan Human Resource } \\
\text { Scorecard Dalam Mengukur }\end{array}$ & $\begin{array}{l}\text { HR Scorecard (empat } \\
\text { perspektif, financial, } \\
\text { customer, operational, } \\
\text { dan strategic) }\end{array}$ & Bussiness Group & $\begin{array}{l}\text { Berdasarkan analisis } \\
\text { SWOT dan cascading } \\
\text { process dari level } \\
\text { pervsahaan hingga turun } \\
\text { ke level divisi } \\
\end{array}$ & $\begin{array}{l}\text { Ada analisis } \\
\text { strategy map dan } \\
\text { hubungan sebab- } \\
\text { akcibat KPI setelah } \\
\text { pengukuran } \\
\end{array}$ \\
\hline
\end{tabular}

\section{SIMPULAN}

Berdasarkan hasil pengumpulan dan pengolahan data yang telah dilakukan maka didapatkan kesimpulan untuk menjawab tujuan penelitian ini. Metode pengukuran kinerja dengan Human Resource Scorecard membantu divisi rekrutmen XYZ Group dalam menghubungkan strategi divisi rekrutmen XYZ Group dengan strategi XYZ Group untuk mencapai visi XYZ Group. Proses pengukuran dilakukan dengan melakukan pengumpulan data mengenai visi XYZ Group, profil XYZ Group dan job description divisi rekrutmen XYZ Group 
untuk dibentuk strategi-strategi divisi rekrutmen XYZ Group. Strategi divisi rekrutmen XYZ Group merupakan hasil penurunan (cascading process) dari strategi XYZ Group hingga mencapai strategi divisi rekrutmen XYZ Group. Hasil dari strategi ini adalah KPI yang berjumlah 17 buah. KPI ini terdiri dari $2 \mathrm{KPI}$ perspektif financial, $2 \mathrm{KPI}$ perspektif customer, $8 \mathrm{KPI}$ perspekif operational, dan $4 \mathrm{KPI}$ perspektif strategic. Pengukuran kinerja dengan Human Resource Scorecard dilakukan dengan menentukan bobot dari perspektif hingga masing-masing KPI. Hasil pengukuran kinerja menunjukkan kinerja keseluruhan mendapatkan skor sebesar 3,506 yang berarti kinerja dari divisi rekrutmen XYZ Group termasuk baik. Kinerja keseluruhan terdiri dari kinerja perspektif strategic yang memiliki nilai terbesar yaitu 4,340 yang berarti kinerja sangat baik, urutan kedua adalah perspektif customer dengan nilai sebesar 3,831 yang berarti kinerja baik, urutan ketiga adalah perspektif operational yang memiliki nilai sebesar 3,423 yang berarti kinerja baik, dan kinerja perspektif financial memiliki nilai kinerja terendah sebesar 2,5 yang berarti kinerja cukup. Performance dashboard untuk divisi rekrutmen XYZ Group terdiri dari satu halaman utama yang berisikan kinerja perspektif dan beberapa KPI sesuai dengan kebutuhan. Berdasarkan hasil pengukuran kinerja yang didapatkan maka dilakukan action plan terhadapan KPI-KPI yang masih di bawah standar pengukuran yaitu memiliki nilai denga kategori kinerja buruk.

\section{PUSTAKA ACUAN}

Mangkunegara, A.A. Anwar Prabu. 2006. Perencanaan dan Pengembangan Manajemen SumberDaya Manusia. Bandung: PT Refika Aditama.

Anthony, Atkinson, et al. 1995. Management Accounting, International Edition. New Jersey: Prantice-Hall International Inc.

Ayu, Mustika. 2017. Perancangan Sistem Pengukuran Kinerja Dengan Metode HR Scorecard Pada Sub-Bidang SDM di PT PLN (Persero) Pusat Pengatur Beban (P2B) Kantor Induk. Skripsi, Universitas Surabaya.

Banerjee, J., \& Buoti, C.2012. General specifications of KPIs. International Telecomunnication Union.

Becker, Brian E., Mark A. Heselid, Dave Ulrich. 2001.The HR Scorecard Linking People, Strategy, and Performance. Boston, Massachusstets: Harvard Business School Press.

Depdikbud. 1988. Kamus Besar Bahasa Indonesia. Jakarta: Balai Pustaka. Hessel, Nogi., 2005. Manajemen Publik. Jakarta: PT Gramedia Widiasarana.

Kaplan, Robert S. \& David P. Norton. 2004. Strategy Maps : Converting Intangible Assets into Tangible Assets. Boston, Massachusstets: Harvard Bussiness School Press.

Krisianti, Winda. 2003. Analisis dan Perancangan Human Resources Scorecard Pada Divisi HRD diPT.Panggung Electric Corporation. Skripsi. Universitas Surabaya.

Kurniawan, Yohanes. 2016. Penyususnan Alat Ukur Kinerja Bagian Personalia Rumah Sakit $X$ dengan Metode Human Resource Scoercard. Skripsi. Universitas Indonesia.

Mulyadi. 2007. Sistem Terpadu Pengelolaan Kinerja Personel Berbasis Balance Scoercard. Jakarta :PT. Gramedia Pustaka Utama.

Muslim, Erlinda \& Frinda Firania. 2016. Designing The Human Resource Scoercard As A Perdormance Measurement of Human Resource. Skripsi. Universitas Indonesia.

Pella, Darmin \& A. Inayati, Ahmad., 2011. Talent Management: Mengembangkan SDM. Jakarta:PT Gramedia Pustaka Utama.

Rangkuti, Freddy. 2013. Analisis SWOT Teknik Membedah Kasus Bisnis. Jakarta; Gramedia PustakaUtama.

Saaty, Thomas L . 1983. Decision Making For Leaders: The Analytical HierarchyProcess for Decisionin Complex World. Pittsburgh: RWS Publication.

Saaty, Thomas L. 1993. Pengambilan Keputusan Bagi Para Pemimpin, Proses Hirarki Analitik untuk Pengambilan Keputusan dalam Situasi yang Kompleks. Jakarta:Pustaka Binama Pressindo. 
Marten, E., et al., Perancangan Human Resource Scorecard untuk Mengevaluasi Kinerja Divisi Rekrutmen XYZ Group, KELUWIH: Jurnal Sains dan Teknologi, Vol.2 (1), 16-29, Februari 2021

https://doi.org/10.24123/saintek.v2i1.4048

Ulrich, Dave. 1997. Human Resource Champion . Boston, Massachusstets: Harvard Bussiness School Press.

W. Eckerson, Wayne. 2010. Performance Dashboards Measuring, Monitoring, and Managing yourBussiness. Canada; John Wiley \& Sons, Inc.

Wibisono, Dermawan. 2006. Manajemen Kinerja, Konsep, Desain, dan TeknikMeningkatkan DayaSaing Perusahaan. Jakarta. Erlangga. 